\title{
OXYGEN UPTAKE IN VENTILATED CHILDREN DURING METHOXYFLURANE ANAESTHESIA
}

\author{
H.I.A. NisBeT, M.B., CH.B., F.F.A.R.C.S.(ENG.), F.R.C.P.(c), \\ T.L. DobBinson, M.B., CH.B., F.F.A.R.A.C.S., \\ T.A. THOMAS, M.B., CH.B., F.F.A.R.C.S. (ENG), AND \\ D.A. Pelton, M.D., F.R.C.P.(C) \\ With the technical assistance of G. VoLGYEsI
}

\section{INTRODUCTION}

IN CHILDREN the alveolar ventilation ( $\dot{V} A$ ) required to maintain a normal arterial carbon dioxide tension $\left(\mathrm{PaCO}_{2}\right)$ is usually calculated from nomograms such as those constructed by Engstrom et al ${ }^{1,2}$ These make use of values for oxygen consumption ( $\dot{\mathrm{V}}_{2.2}$ ) which may be too high. ${ }^{3}$

In adults $\dot{\mathrm{V}} \mathrm{O}_{2}$ appears to vary with the anaesthetic technique. Wylie and Churchill-Davidson ${ }^{4}$ quote a value of $150 \mathrm{ml} / \mathrm{min}$ for $\dot{\mathrm{VO}}_{2}$ during light anaesthesia. During spontaneous ventilation Severinghaus and Cullen ${ }^{5}$ found a mean fall of 22 per cent from basal predicted $\dot{\mathrm{V}}_{2.2}$ in six subjects breathing halothane. Available data suggest that anaesthesia usually reduces $\dot{\mathrm{V} O}$. by 15 per cent of basal values and artificial ventilation causes an additional fall of 6 per cent. ${ }^{6}$ During nitrous oxide anaesthesia however Nunn, Bergman and Coleman ${ }^{3}$ found a mean $\dot{\mathrm{V}}_{2}$ of $215 \mathrm{ml} / \mathrm{min}$ in 200 patients, representing 99 per cent of basal requirements.

Few reports exisi of $\dot{\mathrm{V}} \mathrm{O}_{2}$ in children under 15 years of age undergoing anaesthesia. Owen-Thomas et al. ${ }^{7}$ found that in curarised, anaesthetized infants mean $\dot{\mathrm{V}}$. . was $8.9 \mathrm{ml} / \mathrm{kg} / \mathrm{min}$, slightly higher than the value of $8.5 \mathrm{ml} / \mathrm{kg} / \mathrm{min}$ reported by Lees $e t a l .^{8}$ for sleeping and sedated infants. In addition children with congenital heart disease have a high $\dot{\mathrm{V}}_{22}$ in relation to their body weight. ${ }^{8}$

Since $\mathrm{VO}_{2}$ varies with the anaesthetic technique and the patient, using a nomogram may lead to over-ventilation or under-ventilation of the lung. In view of the importance of $\mathrm{VO}_{2}$ in calculating the tidal volume required by children, we measured oxygen consumption in children without cardiac or respiratory disease who were undergoing orthopaedic operations on the limbs, and also in children undergoing correction of congenital anomalies of the heart. In both groups $\dot{\mathrm{V}}_{2}$, was measured under methoxyflurane anaesthesia. We then compared the values measured under these conditions with predicted basal values and calculated the

From the Department of Anaesthesia, The Research Institute, The Hospital for Sick Children, Toronto, Canada and the Department of Anaesthesia, The University of Toronto, Canada.

Address for Reprints: Dr. H.I.A. Nisbet, Department of Anaesthesia, The Hospital for Sick Children, 555 University Avenue, Toronto 101, Ontario, Canada.

This work was supported by a grant from Physicians' Services Incorporated Foundation. A grant from the Canadian Red Cross Youth, Ontario, contributed to the cost of apparatus used in the investigation.

Paper read by Dr. H.I.A. Nisbet to the Canadian Anaesthetists' Society Meeting, Halifax, June 18-22, 1972. 
NISBET, et al.: OXYGEN CONSUMPTION UNDER METHOXYFLURANE

TABLE I

Normal Children; $\mathrm{VO}_{2}$ AND BSA

\begin{tabular}{|c|c|c|c|c|}
\hline No. & $\begin{array}{l}\text { Wt } \\
\mathrm{kg}\end{array}$ & $\begin{array}{l}\text { BSA } \\
\left(\mathrm{m}^{2}\right)\end{array}$ & $\begin{array}{c}\dot{\mathrm{VO}}{ }_{2} \\
\mathrm{ml} / \mathrm{min}\end{array}$ & $\begin{array}{c}\dot{\mathrm{V}} \mathrm{O}_{2} \\
\mathrm{ml} / \mathrm{kg} / \mathrm{min}\end{array}$ \\
\hline 1 & 19.3 & 0.78 & 104.0 & 5.39 \\
\hline 2 & 29.0 & 1.02 & 146.0 & 5.03 \\
\hline 3 & 31.0 & 1.04 & 146.0 & 4.71 \\
\hline 4 & 18.8 & 0.78 & 100.5 & 5.35 \\
\hline 5 & 49.7 & 1.45 & 143.1 & 2.88 \\
\hline 6 & 60.0 & 1.71 & 185.7 & 3.10 \\
\hline 7 & 70.1 & 1.91 & 209.0 & $\begin{array}{l}2.98 \\
2.10\end{array}$ \\
\hline 8 & 38.5 & 1.22 & 149.0 & 3.87 \\
\hline 9 & 51.1 & 1.51 & 184.0 & 3.60 \\
\hline 10 & 60.6 & $\begin{array}{l}1.69 \\
\text {. }\end{array}$ & 178.8 & $\begin{array}{l}2.00 \\
2.93\end{array}$ \\
\hline 11 & 42.2 & 1.34 & 155.0 & 3.69 \\
\hline 12 & 21.4 & 0.85 & 103.2 & 4.90 \\
\hline 13 & 27.0 & 0.95 & 115.6 & 4.26 \\
\hline 14 & 29.0 & 1.01 & 134.0 & 4.62 \\
\hline 15 & 49.4 & 1.48 & 153.3 & 3.10 \\
\hline 16 & 35.4 & 1.21 & 148.5 & 4.21 \\
\hline 17 & 61.0 & 1.71 & 196.6 & 3.23 \\
\hline 18 & 71.0 & 1.97 & 216.3 & 3.04 \\
\hline 19 & 38.0 & 1.16 & 155.4 & 4.08 \\
\hline 20 & 16.0 & 0.65 & 092.3 & $\begin{array}{l}5.75 \\
5.75\end{array}$ \\
\hline 21 & 36.5 & 1.26 & 127.5 & 3.48 \\
\hline $\mathrm{n}$ & 21 & 21 & 21 & 21 \\
\hline$\overline{\mathbf{x}}$ & 40.7 & 1.27 & & 4.01 \\
\hline SD & 17.03 & 0.375 & & 0.917 \\
\hline
\end{tabular}

$\mathrm{n}=$ number of cases.

$\overline{\mathbf{x}}=$ mean value.

$\mathrm{SD}=$ standard deviation.

effect of $a \pm 20$ per cent variation in measured and in predicted $\dot{\mathrm{V}} \mathrm{O}_{2}$ upon the required $\dot{V} A$.

\section{METHODS}

Twenty-one children without clinical evidence of cardiac or respiratory disease undergoing orthopaedic operations upon the limbs, were designated normal for this study (Tables $\mathrm{I}$ and II). Their ages ranged from 5 years to 18 years. $\mathrm{VO}_{2}$ was also measured in 16 children, from 5 to 16 years of age who were undergoing operations for repair of various congenital heart anomalies (Tables III and IV).

\section{Preliminary Experiments}

Since the accuracy of $\dot{\mathrm{V}}_{2}$ measurements obtained by spirometry is reportedly less than that obtained by gas collection ${ }^{10}$ we compared the values for $\mathrm{VO}_{2}$ derived by both methods in dogs. ${ }^{9}$ The mean value for $\dot{\mathrm{V}}^{\circ} .2$ obtained in dogs by spirometry was higher than the mean values obtained by expired gas collection (Table V).

\section{Patient Studies - Anaesthetic Technique}

Anaesthesia was induced in all patients with thiopentone (up to $5 \mathrm{mg} / \mathrm{kg}$ ) with atropine $(0.02 \mathrm{mg} / \mathrm{kg})$. The child was then intubated with a cuffed tracheal tube after administering succinylcholine chloride. The cuff on the tube was inflated sufficiently to prevent leaks from the anaesthetic circuit. Anaesthesia was maintained with methoxyflurane ( 0.5 per cent to 1 per cent) in either pure oxygen or a 
TABLE II

Normal Children; Heat Output in Comparison with Basal Values

\begin{tabular}{|c|c|c|c|c|c|c|}
\hline \multirow[b]{2}{*}{ No. } & \multirow[b]{2}{*}{$\begin{array}{l}\text { Age, } \\
\text { years }\end{array}$} & \multirow[b]{2}{*}{ Sex } & \multicolumn{4}{|c|}{ Heat Output (Calories $/ \mathrm{m}^{2} / \mathrm{hr}$ ) } \\
\hline & & & Predicted* & Measured & Difference & $\begin{array}{l}\text { Per Cent } \\
\text { Difference }\end{array}$ \\
\hline 1 & 5 & M & $56.3^{\prime}$ & 38.6 & -17.7 & -24 \\
\hline$\overline{2}$ & 6 & $F$ & 51.8 & 41.4 & -10.4 & -20 \\
\hline 3 & 8 & $\mathbf{M}$ & 50.1 & 41.4 & $-08 . \overline{7}$ & -17 \\
\hline 4 & 11 & $\mathrm{~F}$ & 42.4 & 37.3 & -05.1 & -12 \\
\hline$\overline{5}$ & 13 & $\mathrm{~F}$ & 39.1 & 28.6 & -10.5 & -27 \\
\hline 6 & 18 & M & 39.2 & 31.4 & -07.8 & -20 \\
\hline 7 & 14 & M & 41.8 & 31.7 & -10.1 & -24 \\
\hline 8 & 9 & M & 48.2 & 35.4 & -12.8 & -27 \\
\hline 9 & 14 & M & 41.8 & 35.4 & -06.4 & -15 \\
\hline 10 & 18 & M & 39.2 & 30.6 & -08.6 & -22 \\
\hline 11 & 11 & $\mathrm{~F}$ & 42.4 & 33.5 & -08.9 & -21 \\
\hline 12 & 7 & M & 52.1 & 35.3 & -16.8 & -32 \\
\hline 13 & 6 & $\mathrm{~F}$ & 51.8 & 35.3 & -16.5 & -32 \\
\hline 14 & 10 & M & 46.6 & 38.4 & -08.2 & -18 \\
\hline 15 & 12 & $\mathrm{~F}$ & 40.6 & 30.0 & -10.6 & -26 \\
\hline 16 & 13 & $\mathrm{~F}$ & 39.1 & 35.5 & -03.6 & -09 \\
\hline 17 & 12 & M & 43.8 & 33.3 & -10.5 & -24 \\
\hline 18 & 14 & M & 41.8 & 31.8 & -10.0 & -24 \\
\hline 19 & 9 & $\mathbf{M}$ & 48.2 & 38.8 & -09.4 & -20 \\
\hline 20 & 6 & M & 54.2 & 41.0 & -13.2 & -24 \\
\hline 21 & 15 & M & 41.0 & 29.3 & -11.7 & -29 \\
\hline$\frac{n}{x}$ & & & 21 & 21 & $\begin{array}{r}21 \\
-10-5\end{array}$ & $\begin{array}{r}21 \\
-92\end{array}$ \\
\hline $\begin{array}{l}\bar{x} \\
\text { SD }\end{array}$ & & & $\begin{array}{c}45.3 \\
5.57\end{array}$ & $\begin{array}{r}34.8 \\
4.0\end{array}$ & $\begin{array}{r}-10.5 \\
3.18\end{array}$ & $\begin{array}{r}-22 \\
5.9\end{array}$ \\
\hline
\end{tabular}

*From Robertson and Reid" (expected mean value for age and sex).

$\mathbf{n}=$ number of cases.

$\overline{\mathrm{x}}=$ mean value.

$\mathrm{SD}=$ standard deviation.

TABLE III

Children with Congenital Cardiac Anomalies; $\dot{V}_{2}$ and BSA

\begin{tabular}{|c|c|c|c|c|c|}
\hline No. & Diagnosis & Wt kg & $\mathrm{BSA} \mathrm{m}^{2}$ & $\dot{\mathrm{VO}}_{2} \mathrm{ml} / \mathrm{min}$ & $\dot{\mathrm{VO}}_{2} \mathrm{ml} / \mathrm{kg} / \mathrm{min}$ \\
\hline 22 & $T$ of $F$ & 16.0 & 0.69 & 92.0 & 5.75 \\
\hline 23 & $T$ of $F$ & 22.0 & 0.87 & 126.6 & 5.75 \\
\hline 24 & PS & 15.8 & 0.67 & 96.8 & 6.13 \\
\hline 25 & VSD PS & 24.6 & 0.93 & 148.0 & 6.02 \\
\hline 26 & VSD & 27.4 & 0.97 & 140.0 & 5.11 \\
\hline 27 & Coarct & 34.7 & 1.17 & 155.0 & 4.47 \\
\hline 28 & TGV & 24.9 & 0.92 & 116.0 & 4.66 \\
\hline 29 & VSD PS & 19.8 & 0.81 & 125.4 & 6.33 \\
\hline 30 & TGV & 37.2 & 1.28 & 153.0 & 4.11 \\
\hline 31 & $\mathrm{~T}$ of $\mathrm{F}$ & 22.6 & 0.90 & 119.4 & 5.27 \\
\hline 32 & $\mathrm{ASD}$ & 21.1 & 0.83 & 112.1 & 5.31 \\
\hline 33 & ASD & 23.0 & 0.86 & 108.0 & 4.70 \\
\hline 34 & $T$ of $F$ & 22.4 & 0.88 & 99.9 & 4.46 \\
\hline 35 & $\mathrm{~T}$ of $\mathrm{F}$ & 30.3 & 1.06 & 139.0 & 4.59 \\
\hline 36 & PS & 40.4 & 1.32 & 185.0 & 4.58 \\
\hline 37 & $T$ of $F$ & 70.7 & 1.92 & 248.0 & 3.51 \\
\hline$\frac{n}{r}$ & & 16 & 16 & 16 & 16 \\
\hline$\overline{\mathbf{x}}$ & & 28.3 & 1.00 & 135.2 & 5.05 \\
\hline SD & & 13.3 & 0.31 & 39.0 & 0.80 \\
\hline
\end{tabular}

$\mathrm{n}=$ number of cases.

$\overline{\mathbf{x}}=$ mean value.

$\mathrm{SD}=$ standard deviation. 
NISBET, et al.: OXYGEN CONSUMPTION UNDER METHOXYFLURANE

TABLE IV

Children with Congenital Cardiac Anomalies; Heat Output in COMPARISON WITH BASAL VALUES

\begin{tabular}{|c|c|c|c|c|c|c|}
\hline \multirow[b]{2}{*}{ No. } & \multirow[b]{2}{*}{$\begin{array}{l}\text { Age, } \\
\text { years }\end{array}$} & \multirow[b]{2}{*}{ Sex } & \multicolumn{4}{|c|}{ Heat Output (calories $/ \mathrm{m}^{2} / \mathrm{hr}$ ) } \\
\hline & & & Predicted* & Measured & Difference & $\begin{array}{l}\text { Per Cent } \\
\text { Difference }\end{array}$ \\
\hline $\begin{array}{l}22 \\
23 \\
24 \\
25 \\
26 \\
27 \\
28 \\
29 \\
30 \\
31 \\
32 \\
33 \\
34 \\
35 \\
36 \\
37\end{array}$ & $\begin{array}{r}6 \\
8 \\
6 \\
10 \\
7 \\
11 \\
8 \\
8 \\
16 \\
8 \\
6 \\
5 \\
7 \\
13 \\
13 \\
14\end{array}$ & $\begin{array}{l}F \\
F \\
F \\
F \\
F \\
M \\
M \\
M \\
M \\
M \\
M \\
F \\
M \\
M \\
M \\
M\end{array}$ & $\begin{array}{l}51.8 \\
48.4 \\
51.8 \\
44.3 \\
50.2 \\
45.1 \\
50.1 \\
50.1 \\
40.3 \\
50.1 \\
54.2 \\
53.0 \\
52.1 \\
42.7 \\
42.7 \\
41.8\end{array}$ & $\begin{array}{l}38.60 \\
42.13 \\
41.83 \\
46.07 \\
41.78 \\
38.35 \\
36.50 \\
44.82 \\
34.60 \\
38.40 \\
39.10 \\
36.36 \\
32.86 \\
37.96 \\
40.57 \\
37.39\end{array}$ & $\begin{array}{l}-13.2 \\
-06.3 \\
-09.9 \\
+01.8 \\
-08.4 \\
-06.8 \\
-13.6 \\
-05.3 \\
-05.7 \\
-11.7 \\
-15.1 \\
-16.6 \\
-19.2 \\
-04.7 \\
-02.1 \\
-04.4\end{array}$ & $\begin{array}{l}-25 \\
-13 \\
-19 \\
+04 \\
-17 \\
-15 \\
-27 \\
-11 \\
-14 \\
-23 \\
-28 \\
-31 \\
-37 \\
-11 \\
-05 \\
-11\end{array}$ \\
\hline $\begin{array}{c}\mathbf{n} \\
\overline{\mathbf{x}} \\
\mathrm{SD}\end{array}$ & $\begin{array}{l}16 \\
9.1 \\
3.3\end{array}$ & & $\begin{array}{l}16 \\
47.4 \\
4.27\end{array}$ & $\begin{array}{l}16 \\
39.2 \\
3.52\end{array}$ & $\begin{array}{r}16 \\
-07.4 \\
7.56\end{array}$ & $\begin{array}{rl} & 16 \\
-17.7 & 10.44\end{array}$ \\
\hline
\end{tabular}

${ }^{*}$ From Robertson and Reid ${ }^{11}$.

$\mathrm{n}=$ number of cases.

$\overline{\mathbf{x}}=$ mean value.

$\mathrm{SD}=$ standard deviation.

50-50 oxygen-nitrogen mixture. At the first sign of returning spontaneous ventilation, d-tubocurarine $(0.5 \mathrm{mg} / \mathrm{kg})$ was administered intravenously and intermittent positive pressure ventilation (IPPV) started with a tidal volume of 10 millilitres $/ \mathrm{kg}$ body weight. The rate of ventilation was adjusted to maintain $\mathrm{PaCO}_{2}$ or "arterialised" venous $\mathrm{PCO}_{2}$ within normal limits. Rectal or oesophageal temperatures measured in all cases did not vary significantly from $37^{\circ} \mathrm{C}$.

After anaesthesia had been maintained for 15 to 20 minutes, functional residual capacity (FRC) was measured by means of the helium dilution technique ${ }^{9}$ and if this measurement was satisfactory, the amount of oxygen needed to maintain a constant volume in the spirometer during artificial ventilation was recorded. The values for $\dot{\mathrm{V}} \mathrm{O}_{\text {. }}$ were not accepted in cases which showed delay or failure of helium equilibration in the lungs.

\section{Treatment of Data}

In normal children the values for $\dot{\mathrm{VO}}_{2}$ in $\mathrm{ml} / \mathrm{min}$ were plotted against the body surface area (BSA) in square metres $\left(\mathrm{m}^{2}\right)$. $\mathrm{V} \mathrm{O}_{2}$ was then calculated in $\mathrm{ml} / \mathrm{kg} / \mathrm{min}$ and plotted against BSA and age. $\mathrm{VO}_{2}$ was also converted to heat output in calories per square metre per hour (calories $/ \mathrm{m}^{2} / \mathrm{hr}$ ) and this was plotted against age in years and compared to the basal values measured by Robertson and Reid. ${ }^{11}$ In children with congenital cardiac anomalies $\mathrm{V}_{2}$ in $\mathrm{ml} / \mathrm{kg} / \mathrm{min}$ was plotted against BSA and the values compared with those measured in the normal children.

In 7 of the children with cardiac anomalies in whom $\mathrm{PaCO}_{2}$ was measured 
TABLE V

$\dot{\mathrm{VO}}_{2}$ (ML) IN DOGS; CoMparison of METhods

\begin{tabular}{|c|c|c|}
\hline Gas Collection* & Spirometry & $\mathrm{R} \dagger$ \\
\hline 62 & 67.9 & 0.70 \\
\hline 59 & 79.7 & 0.70 \\
\hline 67 & 63.7 & 0.70 \\
\hline 65 & 71.6 & 0.70 \\
\hline 64 & 63.9 & 0.70 \\
\hline 56 & 68.0 & 0.70 \\
\hline 53 & 64.2 & 0.80 \\
\hline 70 & 63.3 & 0.70 \\
\hline 78 & 80.1 & 0.70 \\
\hline 74 & 76.3 & 0.70 \\
\hline 67 & 76.3 & 0.80 \\
\hline 64 & 71.3 & 0.70 \\
\hline 60 & 64.3 & 0.70 \\
\hline 58 & 63.4 & 0.75 \\
\hline & 14 & 14 \\
\hline$\overline{\mathrm{x}} 64.1$ & 69.1 & 0.72 \\
\hline SD $\mathbf{6 . 8 8}$ & 6.25 & 0.037 \\
\hline
\end{tabular}

*VE $\left(\mathrm{F}_{10_{2}}-\mathrm{F}_{\mathrm{EO}_{2}}\right)$.

$\dagger$ Respiratory exchange ratio.

$\mathrm{n}=$ number of cases.

$\overline{\mathrm{x}}=$ mean value.

$\mathrm{SD}=$ standard deviation.

TABLE VI

VA (L/min) (BTPS); Comparison of Measured, Calculated and Predicted Values in Children with Congenital Cardiac Anomalies

\begin{tabular}{|c|c|c|c|c|}
\hline No. & $\begin{array}{c}\mathrm{PaCO}_{2}{ }^{*} \\
(\mathrm{~mm} / \mathrm{mercury})\end{array}$ & Measured & $\dot{\mathrm{VA}} \underset{\text { Calculated } \dagger}{(\mathrm{L} / \mathrm{min})}(\mathrm{BTPS})$ & Predicted \\
\hline 22 & 43.0 & 1.368 & 1.630 & 1.820 \\
\hline 22 & 41.5 & 1. 368 & 1.630 & 1.820 \\
\hline 25 & 44.0 & 1.970 & 2.620 & 2.550 \\
\hline 26 & 35.6 & 2.824 & 2.480 & 2.800 \\
\hline 26 & 38.2 & 2.488 & 2.480 & 2.800 \\
\hline 29 & 35.3 & 2.475 & 2.200 & 2.500 \\
\hline 30 & 35.6 & 3.332 & 2.710 & 3.350 \\
\hline 35 & 36.0 & 3.012 & 2.460 & 2.900 \\
\hline$\frac{\mathrm{n}}{\overline{\mathrm{x}}}$ & 8 & & 8 & \\
\hline $\begin{array}{l}\bar{x} \\
\text { SD }\end{array}$ & $\begin{array}{r}38.7 \\
3.6\end{array}$ & $\begin{array}{l}2.35 \\
0.73\end{array}$ & $\begin{array}{l}2.28 \\
0.42\end{array}$ & $\begin{array}{l}2.57 \\
0.53\end{array}$ \\
\hline
\end{tabular}

and found to be normal (Table VI), $\dot{V A}$ was measured and a comparison was made between the $\dot{V} A$ predicted to maintain a normal $\mathrm{PaCO}_{2}$ from the Engström nomogram, and the ventilation calculated to maintain a $\mathrm{PaCO}_{2}$ at $40 \mathrm{~mm} / \mathrm{Hg}$ calculated from the measured $\dot{\mathrm{VO}}_{2}$.

Finally, an attempt was made to define the range of $\dot{V A}$ required to maintain $\mathrm{PaCO}_{2}$ at $40 \mathrm{~mm} / \mathrm{Hg}$ if we assumed a \pm 20 per cent variation in $\dot{\mathrm{VO}}_{2}$ measured in these children under methoxyflurane anaesthesia from the basal values for $\dot{\mathrm{V} O}$.2 used in the Engström nomogram. 


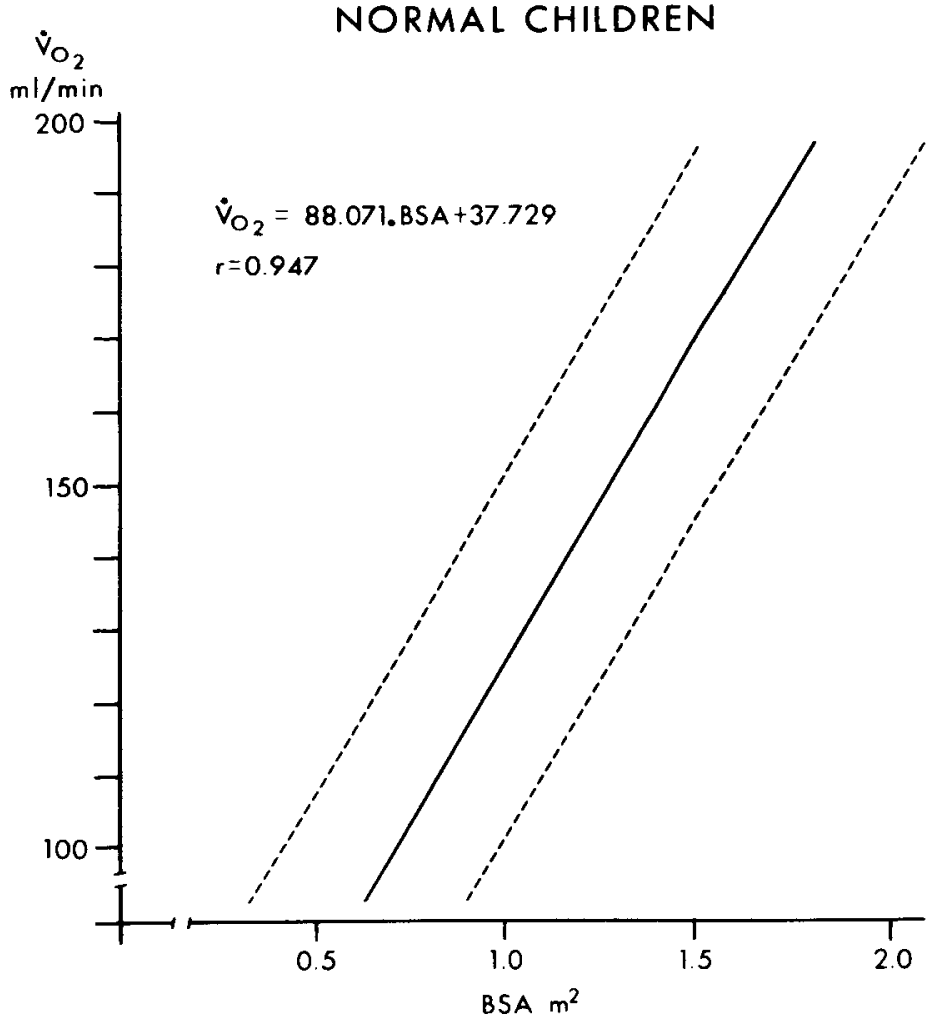

Figune 1. Normal children; $\dot{\mathrm{V}} \mathrm{O}_{2}$ in $\mathrm{ml} / \mathrm{min}$ in relation to BSA.

Results

\section{Patient Studies}

\section{Normal Children}

In normal children $\dot{\mathrm{V}}_{2}$ in $\mathrm{ml} / \mathrm{min}$ correlated well with BSA (Figure 1). The values for $\dot{\mathrm{V}} \mathrm{O}_{2}$ converted to $\mathrm{ml} / \mathrm{min}$ (Table $\mathrm{I}$ ) and plotted against BSA (Figure 2 ) and age (Figure 3 ) showed good correlation.

The values for $\dot{\mathrm{VO}}_{2}$ were converted into heat output in calories $/ \mathrm{m}^{2} / \mathrm{hr}$ and compared to the basal values predicted from the data of Robertson and Reid. ${ }^{11}$ Mean heat output was 22 per cent less than the predicted basal value (Table II). Good correlation was obtained between heat output and age in years (Figure 4). The mean line for heat output in the anaesthetized children diverges more from the predicted basal value of Robertson and Reid in the younger children (Figure 4).

\section{Children with Cardiac Anomalies}

In the children undergoing operation for correction of congenital cardiac anomalies (Table III) $\dot{\mathrm{V}} \mathrm{O}_{\text {.. }}$ in $\mathrm{ml} / \mathrm{kg} / \mathrm{min}$ was in most cases above the mean value for the normal children and sometimes outside the 95 per cent confidence limit (Figure 5 ). The correlation between $\mathrm{VO}_{2}$ and BSA normals or cardiacs was less striking $\left(\mathrm{r}=-0.78 ; \dot{\mathrm{VO}}_{2}=7.087-2.03 \mathrm{BSA}\right)$ and mean heat output was 17.7 per cent below the basal values predicted by Robertson and Reid (Table IV). 


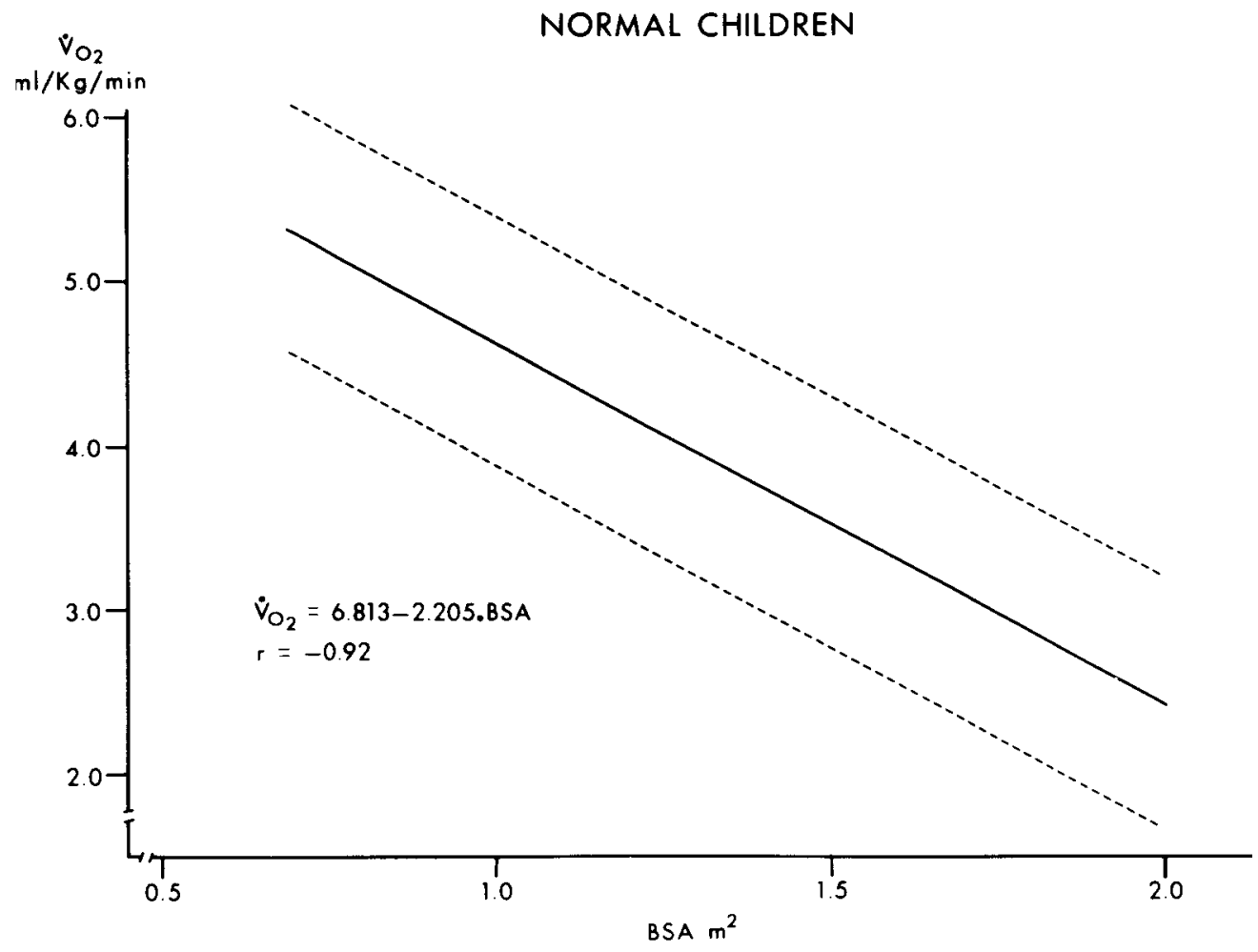

Figure 2. Normal children; $\dot{\mathrm{V}} \mathrm{O}_{2}$ in $\mathrm{ml} / \mathrm{kg} / \mathrm{min}$ in relation to BSA.

In 8 of the children undergoing cardiac surgery in whom $\mathrm{PaCO}_{2}$ was close to normal (mean $38.7 \mathrm{mmHg}$ ), $\dot{\mathrm{VA}}$ measured by gas collection was close to that calculated from the spirometer-measured $\dot{\mathrm{VO}}_{2}$, assuming that $\mathrm{PaCO}_{2}$ equals 40 $\mathrm{mmHg}$. Both the measured and calculated $\dot{V} A$ were below that predicted from the Engström nomograms (Table VI).

If a variation of \pm 20 per cent occurs, the calculated mean $\dot{V} A$, required to maintain $\mathrm{PaCO}_{2}$ at $40 \mathrm{mmHg}$ in these patients lies between 2.11 litres/min and 3.67 litres/min (Table VII).

\section{Discussion}

Factors which cause error in the measurement of oxygen uptake during anaesthesia have been discussed by Nunn and Pouliot. ${ }^{10}$ The spirometer technique is apparently not particularly accurate $( \pm 7 \text { per cent })^{12}$ but errors can be reduced if FRC remains constant, as it does during artificial ventilation, provided nitrous oxide is not used.

Measurements of $\mathrm{VO}_{2}$ by means of expired gas collection are more accurate. Our experiments in dogs indicate that this technique gives values slightly lower than those measured by spirometry. With both methods, reproducible values are obtained from consecutive measurements. It may be that values for $\dot{\mathrm{V}}_{2}$ obtained 


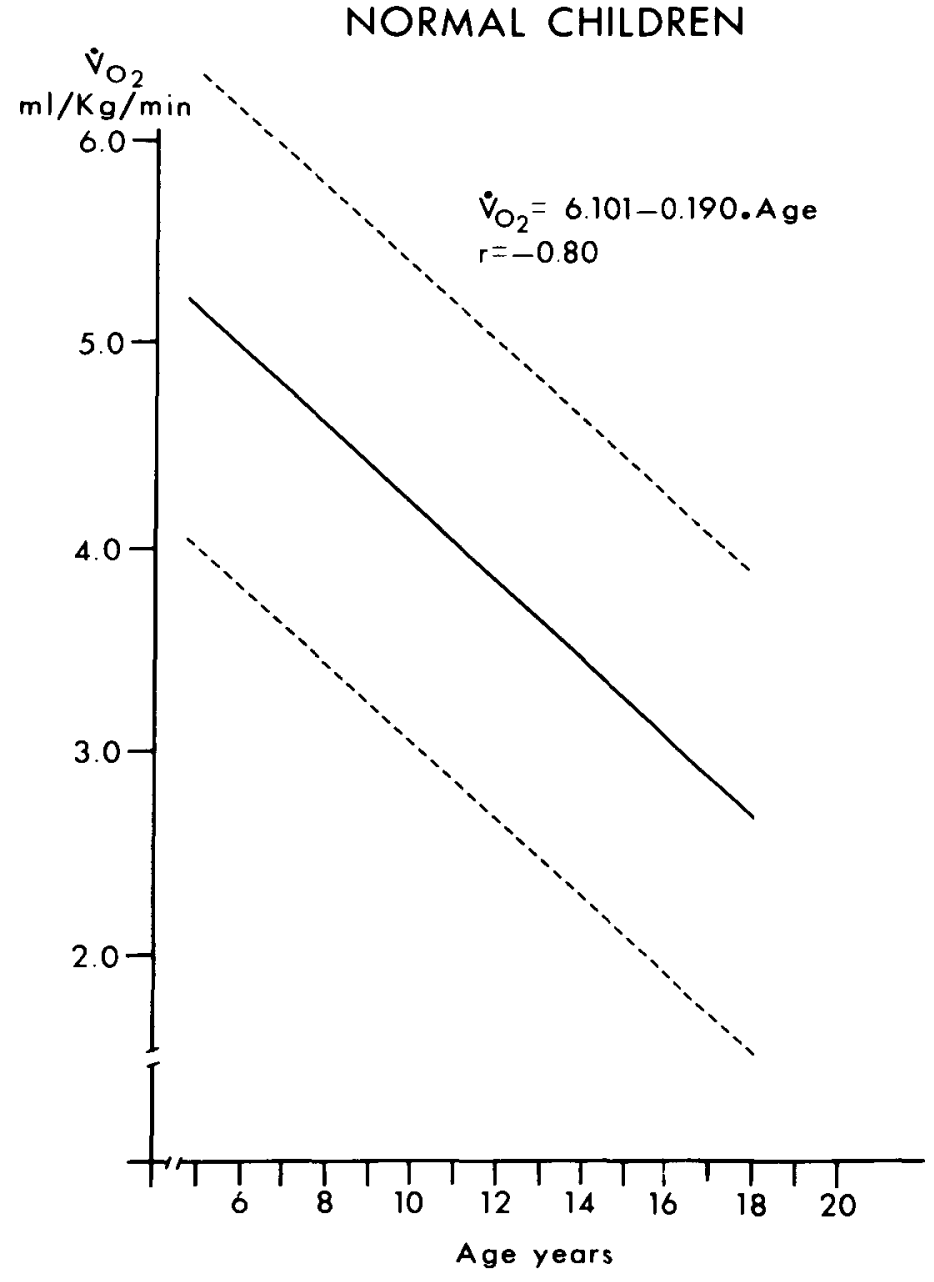

FigUre 3. Normal children; $\dot{\mathrm{VO}}_{2}$ in $\mathrm{ml} / \mathrm{kg} / \mathrm{min}$ in relation to age.

by spirometry during methoxyflurane anaesthesia are a little too high, but the error is not great.

Under nitrous oxide anaesthesia, VO. $_{2}$ reported by Nunn et $a l^{3}$ was 99 per cent of the high basal values measured by Aub and Dubois ${ }^{13}$ and Boothby and Sandiford ${ }^{14}$ and well above the basal values quoted by Robertson and Reid. ${ }^{11}$

In children under methoxyflurane anaesthesia the $\mathrm{V}_{2}$ was 22 per cent below the values reported by Robertson and Reid. Thus it appears that $\mathrm{VO}_{2}$ values vary with the technique and type of anaesthetic, and values are lower when the patient is under methoxyflurane anaesthesia and IPPV than when under nitrous oxide anaesthesia. Our results agree with the prediction that under anaesthesia $\dot{\mathrm{VO}}_{2}$ might drop by 15 per cent from basal levels and that the addition of artificial ventilation might reduce it by a further 6 per cent. ${ }^{8}$ The values we obtained were 22 per cent below the basal levels of Robertson and Reid ${ }^{11}$ which in turn are lower than those of Boothby and Sandiford. 


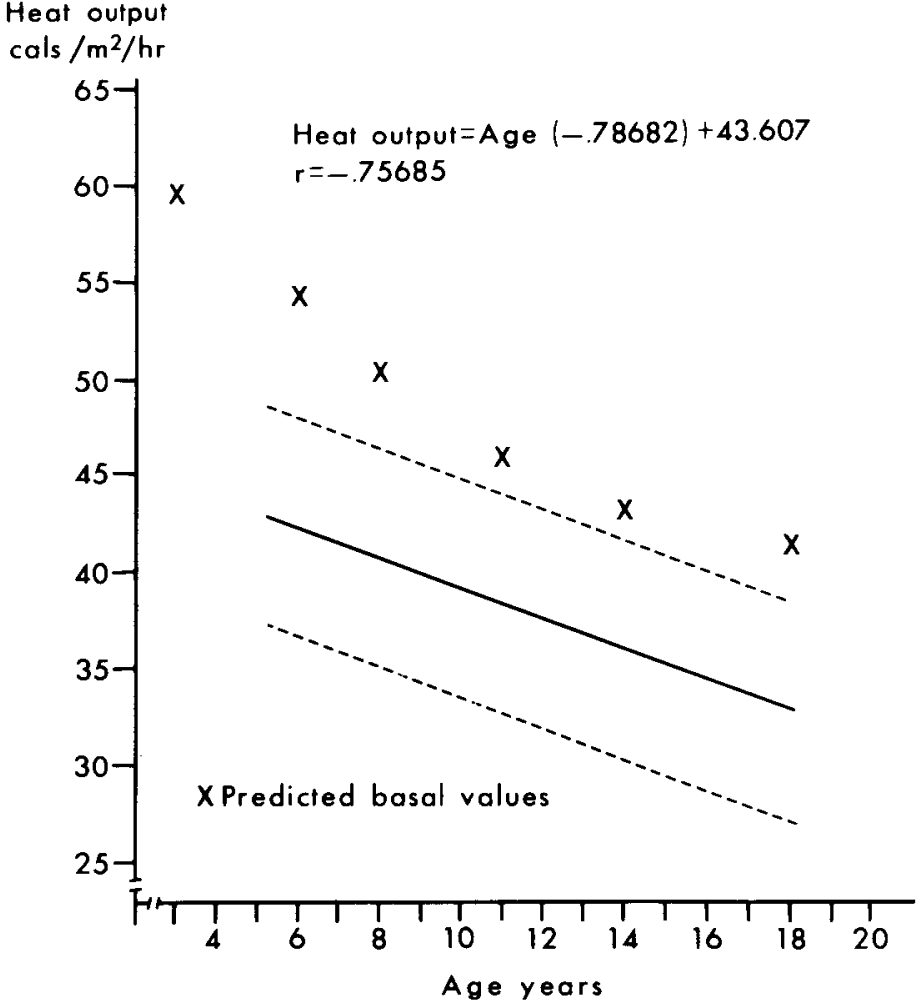

FIgure 4. Normal children; heat output in relation to age, compared with basal values."

The slope of the line relating heat output to age is similar to that derived from the data of Robertson and Reid. The tendency for the lines to diverge in the younger children may mean that, in them, $\dot{\mathrm{vO}}_{2}$ is depressed by methoxyflurane more than in older children.

In children undergoing cardiac surgery, who were the only patients to receive premedication $(2 \mathrm{mg} / \mathrm{kg}$ pentobarbitone, $1.5 \mathrm{mg} / \mathrm{kg}$ pethidine, $0.02 \mathrm{mg} / \mathrm{kg}$ atropine), $\dot{\mathrm{VO}}_{2}$ was high, all but three values lying above the mean for the normal children (Figure 5). These results may have been influenced by the use of atropine, but they agree with the reports of high $\dot{\mathrm{V}} \mathrm{O}_{2}$ relative to body weight in children with congenital heart disease. ${ }^{7}$ No evidence exists that methoxyflurane depresses $\dot{\mathrm{V}}_{2}$ in children undergoing cardiac surgery more than in normal children.

If Engström's nomogram derived from values somewhat higher than those measured by Robertson and Reid was used for children during methoxyflurane anaesthesia and artificial ventilation, over-ventilation would result. The measured VA required to maintain a mean $\mathrm{PaCO}_{2}$ of $38.7 \mathrm{mmHg}$ in the patients during methoxyflurane anaesthesia ( Table VI) was considerably lower than that predicted from

${ }^{*}$ From Robertson and Reid. ${ }^{11}$ 
NISBET, et al.: OXYGEN CONSUMPTION UNDER METHOXYFLURANE

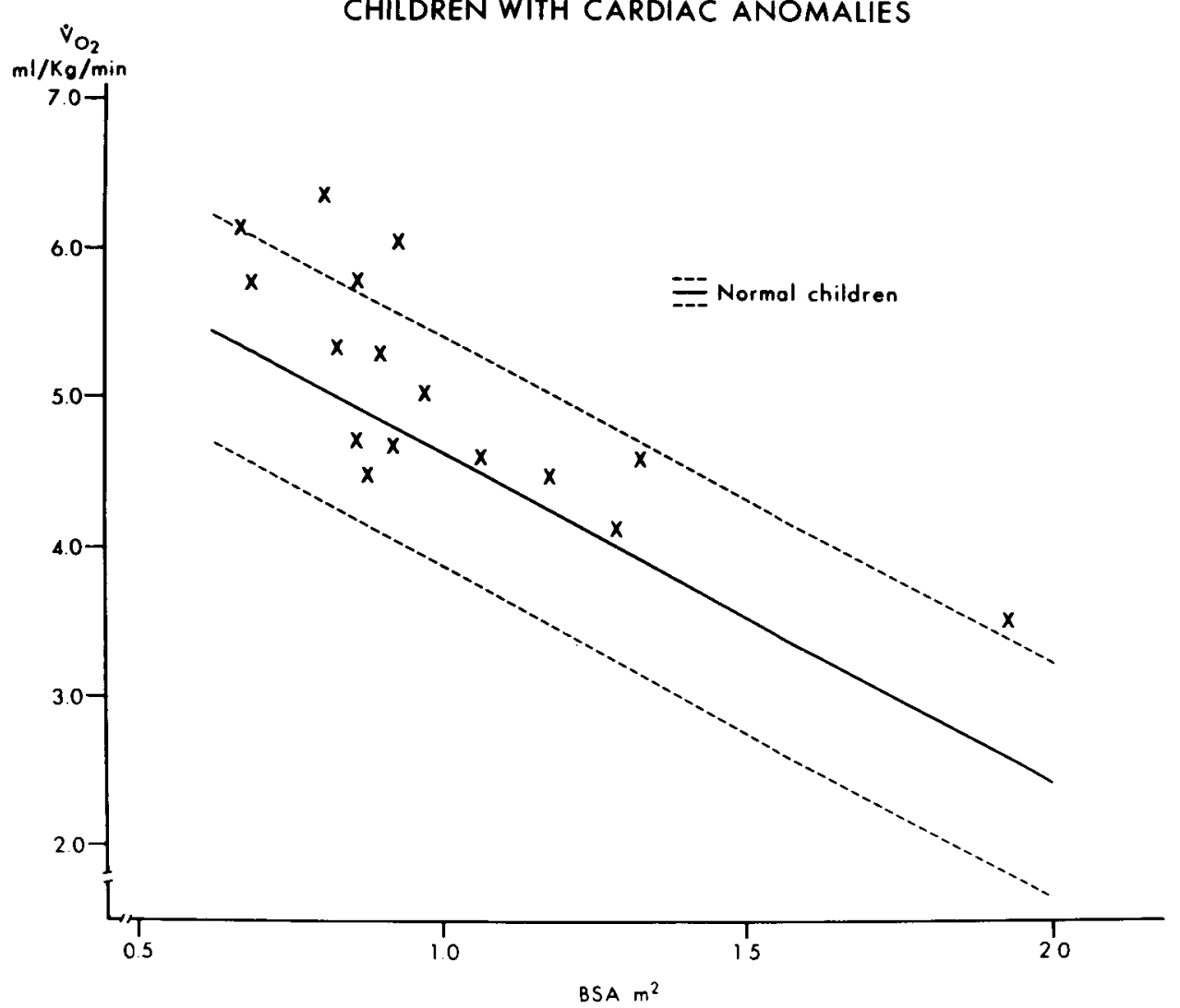

Frgure 5. Children with Congenital Cardiac Anomalies; $\mathrm{VO}_{2}$ in $\mathrm{ml} / \mathrm{kg} / \mathrm{min}$ in relation to BSA, compared with normal children.

TABLE VII

Effect of a \pm 20 Per Cent Variation in $\dot{\mathrm{V}} \mathrm{O}_{2}$ Upon VA

\begin{tabular}{|c|c|c|c|c|c|c|}
\hline No. & $\begin{array}{l}\dot{V} A \text { calculated* } \\
\mathrm{L} / \mathrm{min}\end{array}$ & $+20 \%$ & $-20 \%$ & $\dot{\mathrm{V} A} \underset{\mathrm{L} / \mathrm{min}}{ }$ & $+20 \%$ & $-20 \%$ \\
\hline $\begin{array}{l}22 \\
25 \\
26 \\
29 \\
30 \\
35 \\
37\end{array}$ & $\begin{array}{l}1.63 \\
2.62 \\
2.48 \\
2.21 \\
2.71 \\
2.46 \\
4.39\end{array}$ & $\begin{array}{l}1.95 \\
3.14 \\
2.97 \\
2.65 \\
3.25 \\
2.95 \\
5.26\end{array}$ & $\begin{array}{l}1.31 \\
2.09 \\
1.98 \\
1.77 \\
2.17 \\
1.97 \\
3.51\end{array}$ & $\begin{array}{l}1.82 \\
2.55 \\
2.80 \\
2.50 \\
3.35 \\
2.90 \\
5.40\end{array}$ & $\begin{array}{l}2.20 \\
3.17 \\
3.36 \\
3.00 \\
4.02 \\
3.48 \\
6.48\end{array}$ & $\begin{array}{l}1.46 \\
2.04 \\
2.24 \\
2.00 \\
2.68 \\
2.32 \\
4.32\end{array}$ \\
\hline $\begin{array}{c}\frac{\mathbf{n}}{\mathbf{x}} \\
\mathrm{SD}\end{array}$ & $\begin{array}{l}7 \\
2.64 \\
0.85\end{array}$ & $\begin{array}{l}7 \\
3.18 \\
1.00\end{array}$ & $\begin{array}{l}7 \\
2.11 \\
0.68\end{array}$ & $\begin{array}{l}7 \\
3.05 \\
1.14\end{array}$ & $\begin{array}{l}7 \\
3.67 \\
1.35\end{array}$ & $\begin{array}{l}7 \\
2.46 \\
0.91\end{array}$ \\
\hline
\end{tabular}

${ }^{*}$ From measured $\mathrm{VO}_{2}$ if $\mathrm{PaCO}_{2}=40 \mathrm{~mm} /$ mercury.

†Engstrom.

$\mathrm{n}=$ number of cases.

$\overline{\mathbf{x}}=$ mean value.

$\mathrm{SD}=$ standard deviation. 
the nomogram. Since many anaesthetists prefer the patient to be hyperventilated to some degree, the error is in the direction they desire.

Nunn, et $a l^{3}$ found that $\dot{V}_{2.2}$ in patients anaesthetized with nitrous oxide was 99 per cent of basal. Since they used higher basal values, ${ }^{13,14}$ the ${ }^{1} \mathrm{O}_{2}$, with this agent was well above the basal values of Robertson and Reid. If such large variations in $\dot{\mathrm{V}} \mathrm{O}_{2}$ occur with different types of anaesthesia, prediction of $\dot{\mathrm{VA}}$ required to produce a normal $\mathrm{PaCO}_{2}$ will be difficult.

\section{Conclusions}

$\dot{\mathrm{V}} \mathrm{O}_{2}$ in normal children artificially ventilated during methoxyflurane anaesthesia is 22 per cent below the basal values quoted by Robertson and Reid for children of the same age. Our findings support the suggestion that under light anaesthesia the $\dot{\mathrm{V}} \mathrm{O}_{2}$, will fall by 15 per cent of basal values and artificial ventilation may cause a further fall of 6 per cent. ${ }^{8}$ The values we obtained, however, went 22 per cent below the basal values of Robertson and Reid which in turn are below those of Boothby and Sandiford. ${ }^{14}$

During methoxyflurane anaesthesia and artificial ventilation $\dot{\mathrm{V}} \mathrm{O}_{2}$ and BSA are closely related. In the young child there is a tendency for $\dot{\mathrm{V}} \mathrm{O}_{2}$ to be lower in relation to basal values than in the older child.

$\dot{\mathrm{VO}}_{2}$ in children undergoing surgery for the correction of congenital cardiac anomalies is greater than that measured in normal children under methoxyflurane anaesthesia. The Engström nomogram gives values for $\dot{V} A$ which are too high for children anaesthetized and ventilated with this agent.

Apparently the $\dot{\mathrm{V}}$.2 varies considerably with the type of anaesthetic agent used, making an ideal value for $\dot{V} A$ difficult to predict.

\section{SUMmary}

Few reports exist concerning $\dot{\mathrm{V}}_{2.2}$ in children under anaesthesia between the ages of 3 and 13. During artificial ventilation the required volume can be calculated from standard nomograms but these use values for $\dot{V} \mathrm{O}_{2 .}$ which may be too high under certain anaesthetic conditions.

$\dot{\mathrm{V}} \mathrm{O}_{2}$ was measured in 21 children between the ages of 5 and 18 years undergoing orthopaedic operations upon the limbs and in 16 children, between 5 and 16 years, undergoing surgical repair of congenital anomalies of the heart. In both groups of patients anaesthesia was maintained with methoxyflurane 0.5 to 1 per cent and the children were paralyzed with d-tubocurarine $0.5 \mathrm{mg} / \mathrm{kg}$. They were ventilated with either pure oxygen or 50-50 oxygen-nitrogen mixture using a tidal volume of $10 \mathrm{ml} / \mathrm{kg}$ and adjusting the rate of ventilation to maintain carbon dioxide tension within normal limits.

$\dot{\mathrm{V}}_{2}$ was measured during artificial ventilation using a closed circuit ventilator and spirometer system described for the measurement of functional residual capacity in children. The accuracy of the measurement technique was checked by comparing $\dot{\mathrm{V}}_{2.2}$ measured by spirometry and by gas collection in ventilated dogs. The spirometric method gave slightly higher values. 
Linear correlation between $\mathrm{BSA}$ and $\mathrm{V}_{2}$ was good. In the normal children, the calculated heat output correlated well with age and was 22 per cent below the predicted values of Robertson and Reid. The difference between basal values and heat output during anaesthesia was greater in the younger children.

In the children with cardiac anomalies, mean heat output was 17 per cent below the basal values of Robertson and Reid. $\dot{\mathrm{VO}}_{2}$ in these children was somewhat higher than in the normal group.

It is concluded that $\dot{V}_{2}$, is considerably lower than basal in children under the type of anaesthesia used in this investigation. The results agree with data which suggest that under inhalational anaesthetic agents, $\dot{\mathrm{V}} \mathrm{O}_{2}$ might drop by 15 per cent and the addition of artificial ventilation might reduce it by a further 6 per cent. The use of standard nomograms in order to predict minute ventilation will therefore result in over-ventilation.

\section{RÉSUMÉ}

Il existe peu de travaux qui traitent du $\dot{V} \mathrm{O}_{2}$ chez les enfants anesthésiés dont l'âge varie de 3 à 13 ans. Au cours de la ventilation artificielle, le volume requis peut être calculé d’après les nomogrammes normaux, mais ces nomogrammes emploient des données pour le $\mathrm{V}_{2}$ qui peuvent être trop élevées dans certains états anesthésiques.

Nous avons mesuré le $\mathrm{V}_{2}$ chez 21 enfants dont l'âge variait de 5 à 18 ans au cours de chirurgie orthopédique sut les membres et chez 16 enfants dont lâge variait de 5 à 16 ans, subissant de la chirurgie réparatrice d'anomalies congénitales du cœur. Chez les deux groupes de malades, le maintien de l'anesthésie a été fait avec le méthoxyflurane de 0.5 à 1 pour cent et la paralysie musculaire, avec la $\mathrm{d}$-tubocurarine $0.5 \mathrm{mg} / \mathrm{kg}$. La ventilation a été faite soit avec de l'oxygène pure, soit avec un mélange $50-50$ protoxyde-oxygène et un air courant de $10 \mathrm{ml} / \mathrm{kg}$; la fréquence ventilatoire était fixée de façon à maintenir la tension du $\mathrm{CO}_{2}$ dans les limites de la normale.

Nous avons mesuré le $\dot{\mathrm{V}} \mathrm{O}_{2}$ durant la ventilation artificielle en employant un ventilateur à circuit fermé et un système de spiromètre décrit pour la mesure de la capacité résiduelle fonctionnelle chez les enfants. La précision de la technique de mesure a été vérifiée en comparant par la collection des gaz chez des chiens ventilés. La méthode du spiromètre a donné des résultats un peu plus élevés.

La correlation linéaire entre BSA et le $\dot{\mathrm{V}} \mathrm{O}_{2}$ était bonne. Chez les enfants normaux, le débit débit calorique calculé était en correlation avec l'âge et était de 22 pour cent inférieur aux données prédites de Robertson et Reid. La différence entre les données de base et le débit calorique durant l'anesthésie était supérieure chez les enfants plus jeunes.

Chez les porteur d'anomalies cardiaques, le débit calorique moyen était de 17 pour cent au-dessous des données de base de Robertson et Reid. Le $\dot{\mathrm{V} O}$, , chez ces enfants, était donc plus haut que chez les enfants de l'autre groupe.

Nous concluerons que le $\mathrm{V}_{2}$ est beaucoup plus bas que les données de base chez les enfants soumis à la sorte d'anesthésie employée au cours de cette étude. Les résultats confirment les données qui révèlent que, sous anesthésie par inhalation, le $\dot{\mathrm{VO}}_{2}$ peut diminuer de 15 pour cent et que l'addition de la ventilation artificielle 
peut le réduire d'un 6 pour cent additionnel. En coneéquence, l'utilisation de nomogrammes normaux pour déterminer la ventilation minute va entraîner une surventilation.

\section{ACKNOWLEDGMENT}

We wish to thank the following at the Hospital for Sick Children, Toronto: the Orthopaedic, Cardiovascular and Surgery Divisions for their cooperation, Mrs. Indira Maharaj for her technical assistance, and the Departments of Medical Publications and Visual Education for their help in preparing this paper for publication.

\section{REFERENCES}

1. Engström, C.G., Herzog, P., Norlander, O.P., \& Swensson, S.A. Ventilation nomogram for the newborn and small children to be used with the Engström respirator. Acta. Anaesthesiol. Scand. 6: 175 (1962).

2. Engström, C.G. \& Herzoc, P. Ventilation nomogram for practical use with the Engström respirator. Acta. Chir. Scand. 245: 37 (1959).

3. Nunn, J.F., Bergman, N.A., \& Coleman, A.J. Factors influencing the arterial oxygen tension during anaesthesia with artificial ventilation. Br. J. Anaesth. 37: 898 (1965).

4. Wylie, W.D. \& Churchill-Davidson, H.C. A practice of anaesthesia, 2nd ed. Chicago: Year Book Medical Publishers (1966), p. 85.

5. Severinghaus, J.W. \& Cullen, S.C, Depression of myocardium and body oxygen consumption with fluothane. Anesthesiology 19: 165 (1958).

6. NunN, J.F. Applied respiratory physiology with special reference to anaesthesia, 2nd ed. London: Butterworths (1969), p. 147.

7. Owen-Thomas, J.B., Meade, F., Jones, R.S., \& Rees, G.J. The measurement of oxygen uptake in infants with congenital heart disease during general anaesthesia and intermittent positive pressure ventilation. Br. J. Anaesth. 43: 746 (1971).

8. LeEs, M.H., WAY, R.C., \& Ross, B.B. Ventilation and respiratory gas transfer of infants with increased pulmonary blood flow. Pediatrics 40:259 (1967).

9. Dobbinson, T.L., Nisbet, H.I.A., \& Pelton, D.A. Functional residual capacity (FRC) and compliance in anaesthetized paralyzed children. Pt. I, Methods (in press).

10. NunN, J.F. \& Pouliot, J.C. The measurement of gaseous exchange during nitrous oxide anaesthesia. Br. J. Anaesth. 34: 752 (1962).

11. Robertson, J.D. \& Reid, D.D. Standards for the basal metabolism of normal people in Britain. Lancet 1: 940 (1952).

12. Rotr, P. Modifications of apparatus and improved technique adaptable to Benedict type of respiration apparatus. N. Engl. J. Med. (Boston Med. Surg. J.) 186: 457-463, 491498 (1922).

13. Aub, J.C. \& Dubors, E.F. The basal metabolism of old men. Arch. Intern. Med. 19: 823 (1917).

14. Boothby, W.M. \& Sandiford, I. Basal metabolism. Physiol. Rev. 4: 69 (1924). 